\title{
HIGH-RATE SPUTTERING OF Nb-Al-Ge AND Nb-Al SUPERCONDUCTORS
}

\author{
S. D. Dahlgren
}

\section{MASTER}

\section{ABSTRACT}

High quality $\mathrm{Nb}-\mathrm{Al}-\mathrm{Ge}$ and $\mathrm{Nb}-\mathrm{Al}$ superconductor depsosits were made at a rate of $1 \mu \mathrm{m} / \mathrm{min}$ using high-rate sputtering techniques. Deposits were up to $1 \mathrm{~mm}$ thick. High-rate sputtering reduced fabrication difficulties and significantly increased current capacities. Sputtering equipment capabilities indicate reasonable quantities of high field superconductors can be made by high-rate sputtering for practical application. The $\mathrm{Nb}-\mathrm{Al}-\mathrm{Ge}$ and $\mathrm{Nb}-\mathrm{Al}$ deposits were of high quality as indicated by highly reflective metallic mirror surfaces, even in thicknesses up to $1 \mathrm{~mm}$. Moreover, the deposits were completely void-free and they did not seem to be overly brittle either before or after heat treatment. Crystal structures for deposits made at $10^{\circ} \mathrm{C}$ to $20^{\circ} \mathrm{C}$ were not clearly defined, but probably were body-centered-cubic (bcc). Heat treatment at $550^{\circ} \mathrm{C}$ to $850^{\circ} \mathrm{C}$ completely transformed the bcc deposits to extremely small grains of the A-15 crystal structure. The A-15 phase formed by heat treatment for short times (e.g., $1 \mathrm{hr}$ to 5 days) at $750^{\circ} \mathrm{C}$ was metastable and supersaturated with $\mathrm{Al}$ and $\mathrm{Ge}$. Deposition and heat conditions for decomposition of the metastable A-15 phase were identified. The deposits having the highest critical temperatures $\left(18^{\circ} \mathrm{K}\right)$ consisted only of undecomposed metastable A-15 phase. In order to assess practical use of the sputtered superconductors, one- to two-meter lengths of ribbon and filamentary $\mathrm{Nb}-\mathrm{Al}-\mathrm{Ge}$ superconductor were produced on ribbon and wire substrates. It also was found that an excellent superconductor-stabilizer bond can be formed by high rate sputter-deposition of copper stabilizer onto heat treated $\mathrm{Nb}-\mathrm{Al}-\mathrm{Ge}$ and $\mathrm{Nb}-\mathrm{Al}$ superconductors. 


\section{DISCLAIMER}

This report was prepared as an account of work sponsored by an agency of the United States Government. Neither the United States Government nor any agency Thereof, nor any of their employees, makes any warranty, express or implied, or assumes any legal liability or responsibility for the accuracy, completeness, or usefulness of any information, apparatus, product, or process disclosed, or represents that its use would not infringe privately owned rights. Reference herein to any specific commercial product, process, or service by trade name, trademark, manufacturer, or otherwise does not necessarily constitute or imply its endorsement, recommendation, or favoring by the United States Government or any agency thereof. The views and opinions of authors expressed herein do not necessarily state or reflect those of the United States Government or any agency thereof. 


\section{DISCLAIMER}

Portions of this document may be illegible in electronic image products. Images are produced from the best available original document. 


\section{INTRODUCTION}

Significant advances in applied superconductivity can be expected from the use of sputter-deposited high field superconductors if recent research trends continue. For example, the critical temperature of $\mathrm{Nb}_{3} \mathrm{Ge}$ was raised by Gavaler ${ }^{1}$ to $22.3^{\circ} \mathrm{K}$ with special sputter-deposition techniques, and $\mathrm{Nb}_{3} \mathrm{Ge}$ now has the distinction of having the highest known critical temperature. Moreover, recent results ${ }^{2-4}$ show that high-rate sputter deposition is an excellent method for pro-ducing high quality $\mathrm{Nb}-\mathrm{Al}-\mathrm{Ge}$ and $\mathrm{Nb}_{3} \mathrm{Al}$ superconductors. Thick sputter-deposited $\mathrm{Nb}_{12} \mathrm{Al}_{3} \mathrm{Ge}$ made at a rate of $1 \mu / \mathrm{min}$. had critical currents at $4.2^{\mathrm{O}} \mathrm{K}$ up to $4.4 \times 10^{5} \mathrm{~A} / \mathrm{cm}^{2}$ at $100 \mathrm{kOe},{ }^{2} \mathrm{~A} / \mathrm{cm}^{2}$ at $150 \mathrm{kOe},{ }^{3}$ and at $200 \mathrm{kOe} ;{ }^{3}$ critical temperatures were up to $18.5^{\circ} \mathrm{K} .{ }^{2,4}$ The high critical currents were attributed to.the formation of extremely small, $350 \AA$ diameter grains during heat treatment. ${ }^{2,4}$ The critical currents for $\mathrm{Nb}-\mathrm{Al}-\mathrm{Ge}$ are comparable at all fields to those for $\mathrm{Nb}_{3} \mathrm{Sn}$ and $\mathrm{V}_{3} \mathrm{Ga}$, which are the current leading materials for applications above $100 \mathrm{kOe}$.

The full potential of $\mathrm{Nb}-\mathrm{Al}-\mathrm{Ge}$ and $\mathrm{Nb}-\mathrm{Al}$ superconductors has not been realized due to fabrication limitations that sputter deposition can overcome. Specifically, critical fields for $\mathrm{Nb}-\mathrm{Al}-\mathrm{Ge}(410 \mathrm{kOe})^{5,6}$ and $\mathrm{Nb}_{3} \mathrm{Al}(295 \mathrm{kOe})^{\mathbf{b}^{5}}$ are much higher than those for $\mathrm{Nb}_{3} \mathrm{Sn}(225 \mathrm{kOe})^{7}$ and $\mathrm{V}_{3} \mathrm{Ga}(210 \mathrm{kOe}) . \$ 7$ Critical temperatures of $\mathrm{Nb}-\mathrm{Al}-\mathrm{Ge}\left(20.7^{\mathrm{O}} \mathrm{K}\right)$ and $\mathrm{Nb}_{3} \mathrm{Al}\left(18.7^{\circ} \mathrm{K}\right)^{q}$ also are higher than those for $\mathrm{Nb}_{3} \mathrm{Sn}\left(18.3^{\mathrm{o}} \mathrm{K}\right){ }^{g}$ and $\mathrm{V}_{3} \mathrm{Ga}\left(14.5^{\mathrm{o}} \mathrm{K}\right) .^{7} \cdot \mathrm{V}_{3} \mathrm{Ga}$ is currently the best choice for applications abọve 150 kOe due to its greater current capacity, 10 but the high cost of $\mathrm{Fa}$ alone is sufficient reason to encourage development of lower cost superconductors containing $\mathrm{Nb}, \mathrm{Al}$, and $\mathrm{Ge}$. 1 . 


\section{SPUTTERING CAPABILITY}

High rate sputtering has advanced to the point where rather massive deposits can be made at quite high rates. A freestanding $1.3 \mathrm{~kg}$ cylinder of a $\mathrm{Cu}-\mathrm{Zr}$ alloy, for example, was sputter deposited at a rate of $1.7 \mu / \mathrm{min}$. Another deposit of the same alloy was $5.5 \mathrm{~kg}$ and up to $1.2 \mathrm{~cm}$ thick. If the same mass $(5.5 \mathrm{~kg})$ of $\mathrm{Nb}-\mathrm{Al}-$ Ge superconductor were to be sputter-deposited in the form of a 1000 A capacity ribbon, the conductor would be $3000 \mathrm{~m}$ long (assuming a current density of $4.4 \times 10^{5} \mathrm{~A} / \mathrm{cm}^{2}$ at $100 \mathrm{kOe}$ and $4.3^{\circ} \mathrm{K}$ ). The cost of sputter-deposited superconductor would not be excessive. Estimates of the material, electrical power, equipment, and operating costs suggest the price of the conductor to be about $\$ 1.67 / \mathrm{kA} \cdot \mathrm{m}$, including stabilizer (Table I) .

TABLE I

Cost Estimate for a One Meter Length of 1000 A Capacity Sputter-Deposited Nb-Al-Ge Superconductor \& Stabilizer

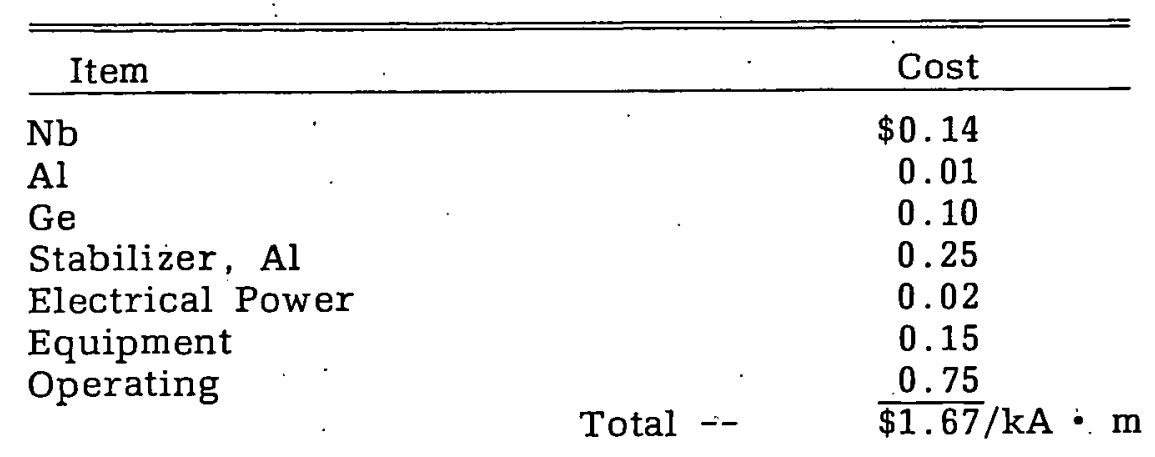




\section{SPUTTER DEPOSITION OF Nb-Al-Ge AND Nb-Al}

The objective of the sputter-deposition work was to form an undecomposed A-15 phase containing 75 at. $\frac{0}{\circ} \mathrm{Nb}$ for compositions where the A-15 phase is not thermodynamically stable. Such metastable compositions were expected to have the highest critical temperatures. It was found that a single, undecomposed A-15 phase of very fine grain size could be made by sputter deposition at a relatively low temperature, e.g. $20^{\circ} \mathrm{C}$, and heat treatment at a moderate temperature, e.g. $750^{\circ} \mathrm{C}$, Figure 1.

Deposits made at $20^{\circ}$ almost certainly had a distorted body-centered cubic (bcc) crystal structure. Only three very broad (bcc $x$-ray diffraction lines were found for $\mathrm{Nb}-\mathrm{Al}-\mathrm{Ge}$, but $\mathrm{Nb}-\mathrm{Al}$ made at $20^{\circ}$ was clearly bcc. $\mathrm{A} \mathrm{Nb}_{3}\left(\mathrm{Al}{ }_{75} \mathrm{Ge} .25\right)$ deposit made at a temperature estimated to be between $50^{\circ} \mathrm{C}$ and $200^{\circ} \mathrm{C}$ also was clearly bcc. The deposits were made at a rate of $1 \mu / \mathrm{min}$. from compacted elemental powder sputtering targets.

Heat treatment at $750^{\circ} \mathrm{C}$ completely transformed the bcc phase to the A-15 phase (Figures 1 and 2). Critical temperatures were low and lattice parameters of the A-15 phase were high for very short heat treatment times, e.g. 1 hr (Figure. 1). The critical temperature reached a maximum of about $18^{\circ} \mathrm{K}$ after heat treatment for 1 to 5 days at $750^{\circ} \mathrm{C}$ (Figure 1). Similarly, the lattice parameter reached a minimum after 5 days (Figure 1). Diffraction lines for extra phases were barely detected in the $\mathrm{x}$-ray diffraction patterns after 5 days, but they were clearly evident after 20 days at $750^{\circ} \mathrm{C}$.

Decomposition of the metastable A-15.phase caused an increase in the $\mathrm{Nb}$ content in the remaining A-15 phase solution as indicated by the increase in the A-15 phase lattice parameter between 5 and 20 days (Figure 1). The critical temperature decreased as a consequence of the change in the A-15 phase composition away from stoiciometric $\left(\mathrm{Nb}_{3}\left(\mathrm{Al} .75^{-\mathrm{Ge}} .25^{\prime}\right)-(\right.$ Figure 1). Sputter-depúsiled 
$\mathrm{Nb}_{3} \mathrm{Al}$ did not decompose quite as readily as $\mathrm{Nb}_{3}\left(\mathrm{Al} .75^{\mathrm{Ge}}{ }_{25}\right)$. Extra phases were not detected in the $\mathrm{Nb}-\mathrm{Al}_{3}$ until after 20 days at $750^{\circ} \mathrm{C}$, and neither the A-15 phase lattice parameter nor the critical temperature changed between 5 days and 20 days at $750^{\circ} \mathrm{C}$. Critical temperatures measured with the four-probe resistance method were quite sharp for $\mathrm{Nb}_{3}-\mathrm{Al}$ after 5 days at $750^{\circ} \mathrm{C}$ (Figure 3), but there was some structure to the curves for $\mathrm{Nb}_{3}\left(\mathrm{Al}{ }_{75} \mathrm{Ge}{ }_{.25}\right.$ after 5 and 20 days at $750^{\circ} \mathrm{C}$ (Figure 4 ).

Several other $\mathrm{Nb}-\mathrm{Al}-\mathrm{Ge}$ compositions were deposited at low temperature $\left(20^{\circ} \mathrm{C}\right)$ and heat treated for 5 days at $750^{\circ} \mathrm{C}$ for comparison of critical temperatures (Table II). The results show that all critical temperatures were above $15^{\circ} \mathrm{K}$, but that $\mathrm{Nb}_{3}\left(\mathrm{Al} .75^{\mathrm{Ge}} .25\right)$ had the highest critical temperatures $\left(17.1\right.$ to $18.3^{\circ} \mathrm{K}$, Table II). One deposit $\left(\mathrm{Nb}_{80.56} \mathrm{Al}_{13.85} \mathrm{Ge}_{5.6}\right)$ did not transform on heat treatment at $750^{\circ} \mathrm{C}$, but it did transform to the A-15 phase after heat treatment for 2 hrs at $1240^{\circ} \mathrm{C}$.

TABLE II

Critical Temperatures for $\mathrm{Six} \mathrm{Nb}-\mathrm{Al}-\mathrm{Ge}$ and $\mathrm{Nb}-\mathrm{Al}$ Compositions after Deposition at $20^{\circ} \mathrm{C}$ and Heat Treatment for 5 Days at $750^{\circ} \mathrm{C}$

\begin{tabular}{|c|c|}
\hline $\begin{array}{c}\text { Deposit } \\
\text { Composition } \\
\end{array}$ & $\begin{array}{l}\text { Critical Transition } \\
\text { Temperature Range, }{ }^{\circ} \mathrm{K}\end{array}$ \\
\hline $\mathrm{Nl}_{75}\left(\mathrm{Al} \cdot .5^{\mathrm{Ge}} \cdot 25^{)}\right.$ & $17 \cdot 1-18.3$ \\
\hline $\mathrm{Nb}_{3} \mathrm{Al}$ & $17.1-17.4$ \\
\hline $\mathrm{Nb}_{75}\left(\mathrm{Al} \cdot 6^{-\mathrm{Ge}}{ }^{-}\right)$ & $15.6-15.9$ \\
\hline $\mathrm{Nb}_{71.67^{\mathrm{Al}}} 23.78_{4.65}^{\mathrm{Ge}_{4}}$ & $16.0-17.2$ \\
\hline $\mathrm{Nb}_{7 n^{\mathrm{Al}}} \mathrm{l}_{30}$ & $15.1-15.9$ \\
\hline $\mathrm{Nb}_{80.56^{\mathrm{Al}}} 13.85^{\mathrm{Ge}_{5.6}}$ & (still bcc) \\
\hline
\end{tabular}


Heat treatment at $1240^{\circ} \mathrm{C}$ verified the conclusion that the single $\mathrm{A}-15$ phases formed at $750^{\circ} \mathrm{C}$ were metastable. The diffraction lines for extra phases were much stronger and there were many more extra lines after heat treatment for 2 hrs at $1240^{\circ} \mathrm{C}$ than after heat treatment for 20 days at $750^{\circ} \mathrm{C}$ (Figure 5). According to the phase diagram, (12) the A-15 phase should be less supersaturated with $\mathrm{Al}$ and $\mathrm{Ge}$ at $1240^{\circ} \mathrm{C}$ than at $750^{\circ} \mathrm{C}$ so the decomposition at $7.50^{\circ} \mathrm{C}$ is limited strictly by reaction kinetics.

Decompsotion of the A-15 phase also occurred immediately in deposits made at elevated temperatures. The A-15 phase formed directly at $485^{\circ} \mathrm{C}$ for $\mathrm{Nb}_{75}$ (Al.${ }_{75} \mathrm{Ge} .25$ ), but diffraction lines for extra phases were already present, and critical temperatures were low even after heat treatment.

\section{SUPERCONDUCTOR FABRICATION}

Work has been started to fabricate useful superconductors by sputterdeposition. One method tried was to pass ribbon and filament substrates from a reel on one side of the sputtering chamber, through the chamber where it was coated, and onto a second reel on the other side of the chamber (Figure 6) . A one-meter long strip of $1.25 / \mathrm{cm}$ wide stainless steel and some two-meter long, 1.25 每 diameter tungsten wire substrates were successfully coated with 2 to $20 \mu$ of $\mathrm{Nb}-\mathrm{Al}-\mathrm{Go}$ superconductor by this method. "Substrate temperatures were rather high for the initial experiments, but lower substrate temperatures are possible now so that optimum superconductor properties can be obtained.

Another potential applied superconductivity use for high-rate sputtering was found during the course of the sputtered superconductor studies. Specifically it is the formation of an excellent mechanical and electrical bond between superconductor and stabilizer. Formation of a good electrical bond between A-15 phase superconductors 
and their stabilizer is often very. difficult. Copper stabilizer has been well bonded to critical current samples by ion etching the heat treated superconductor prior to depositing a high conductivity coating, which then is intimately bonded to the superconductor. The coating need only be thick enough for a copper-tocopper solder joint to be made.

\section{ACKNOWLEDGMENTS}

The author wishes to thank Dr. R.D. Nelson for reviewing the manuscript. The work was sponsored by the USAEC Division of Physical Research. 


\section{REFERENCES}

1. J.R. Gavaler, Phys. Today, Oct. 1973, p. 17.

2. S.D. Dahlgren and D.M. Kroeger, J. Appl. Phys. vol. 44, 5595 (1973) .

3. S.D. Dahlgren, M. Suenaga, and T.S. Luhman (unpublished) .

4. S.D. Dahlgren (unpublished).

5. S. Foner, E.J. McNiff, Jr., B.T. Matthias, T.H. Geballe, R.H. Willens, and E. Corenzwit, Phys. Letters 31A, (1970), p. 349.

6. Kō Yasukōchi, Ryōzēe Akihama, and Nobumitsu Usui, Japan, J. Appl . Phys. 9, (1970) p. 845 .

7. M.S. Lubell, Superconducting Magnet Technology, Proceedings of the International Working Sessions on Fusion Reactor Technology, June 28 July 2, 1971, Conf. 710624, Oak Ridge National Laboratory, Oak Ridge, Tennessee, 37830, p. 236.

8. S. Foner, E.J. McNiff, Jr., B.T. Matthias, and E. Corenzqit, Proc. 11th Intl. Conf. Low Temperature Phys., St. Andrews, Scotland (1969), vol. 2, p. 1025 .

9. R.H. Willens, T.H. Geballe, A.C. Gossard, J.P. Maita, A. Menth, G.W. Hull, Jr., and R.R. Soden, Solid State Commun. 7 (1969), p. 837.

10.. Kyoji Tachikawa, Proceedings of the 1972 Applied Superconductivity Conference, IEEE Publication No. $72 \mathrm{Ch}$ 0682-5-TABSC (IEEE, New York) , p. 371.

11.. James R. Powell, Proceedings of the 1972 Applied Superconductivity Conference, IEEE Publication No. $72 \mathrm{Ch}$ 0682-5-TABSC (IEEE, New York), p. 346.

12. A. Mü, Z. Naturforsch, 25A, 1970, p. 1659, see also English Translation, ORNL-tr-2461, Office of Language Service, Information Div. , Oak Ridge National Lab. , 1971. 
FIGURE 1. A-15 phase lattice parameter and control temperature, $T_{C}$, versus heat treatment time at $750^{\circ} \mathrm{C}$ for sputter-deposited $\mathrm{Nb}_{75}\left(\mathrm{Al}{ }_{.75} \mathrm{Ge}{ }_{25}\right)$ made at $20^{\circ} \mathrm{C}$. The upper $\mathrm{T}_{\mathrm{C}}$ curve give the temperature where superconductivity is first indicated and the lower $T_{C}$ curves give the temperature for a completely superconducting path through the sample, as indicated by the four-probe resistance method.

FIGURE 2. X-ray diffraction pattern for an undecomposed, metastable A-15 phase in an $\mathrm{Nb}_{75}\left(\mathrm{Al}{ }_{.75} \mathrm{Ge}{ }_{.25}\right)$ sputter deposit made at $20^{\circ} \mathrm{C}$ and heat treated 1 day at $750^{\circ} \mathrm{C}$.

FIGURE 3. Critical transition temperature range for $\mathrm{Nb}{ }_{3}^{\mathrm{Al}}$ sputter deposited at $20^{\circ} \mathrm{C}$ and heat treated 5 days at $750^{\circ} \mathrm{C}$.

FIGURE 4. Critical transition temperature ranges for $\mathrm{Nb}_{3}(\mathrm{Al} .75 \mathrm{Ge} .25$ ) made at $20^{\circ} \mathrm{C}$ and heat treated 5 days at $750^{\circ} \mathrm{C}$ (left) and 20 days at $750^{\circ} \mathrm{C}$ (right).

FIGURE 5 . X-ray diffraction pattern for an $\mathrm{Nb}_{75}\left(\mathrm{Al}{ }_{.75} \mathrm{Ge}{ }_{25}\right)$ deposit after heat treatment for two hours at $1240^{\circ} \mathrm{C}$ showing significant decomposition of the A-15 phase.

FIGURE 6. Assembled reel-to-reel equipment for sputter-deposition of Nb-Al$\mathrm{Ge}$ and $\mathrm{Nl}-\mathrm{Al}$ superconductors on ribbon and filament substrates. 

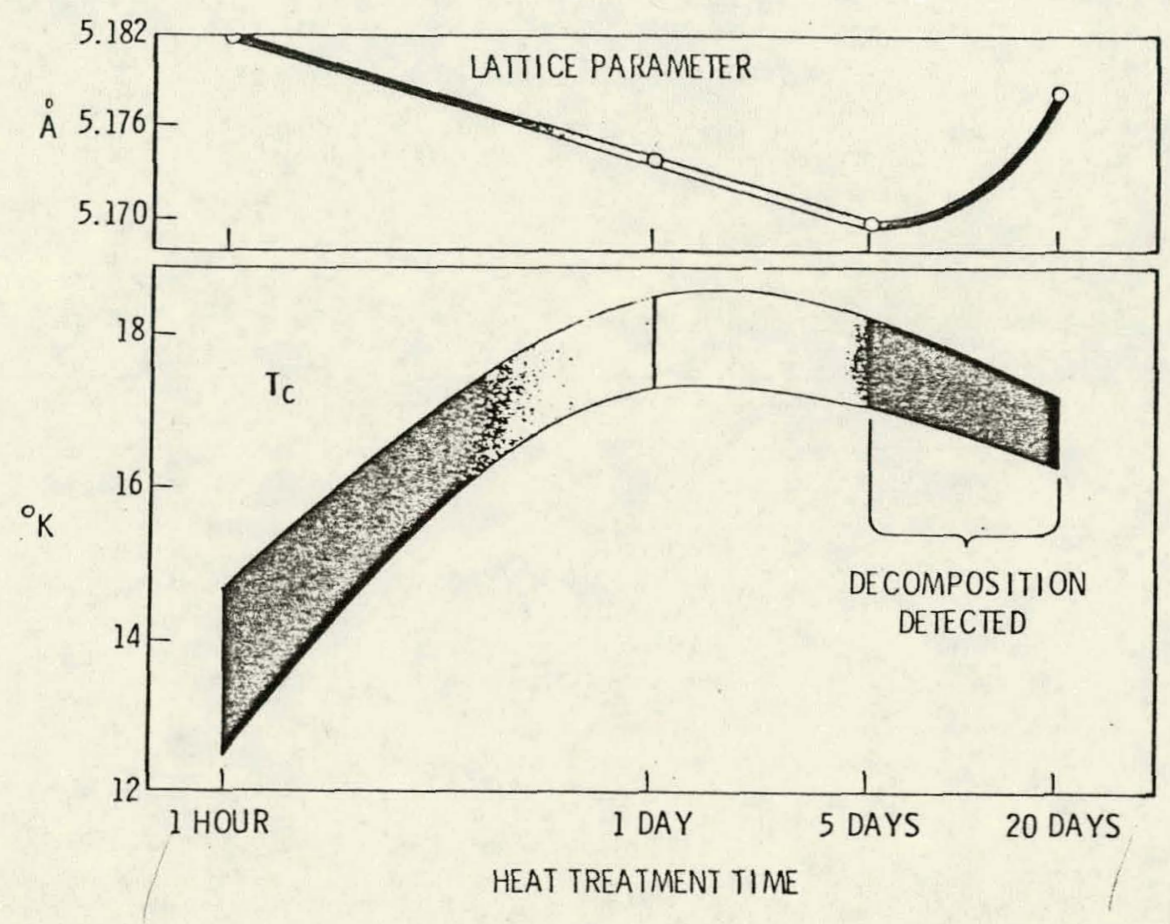

FIGURE 1. A-15 phase lattice parameter and control temperature, $T_{C}$, versus heat treatment time at $750^{\circ} \mathrm{C}$ for sputter-deposited $\mathrm{Nb}_{75}$ ( $\mathrm{Al} .{ }_{75} \mathrm{Ge} .25$ ) made at $20^{\circ} \mathrm{C}$. The upper $\mathrm{T}_{\mathrm{C}}$ curve give the temperature where superconductivity is first indicated and the lower $T_{C}$ curves give the temperature for a completely superconducting path through the sample, as indicated by the four-probe resistance method. 


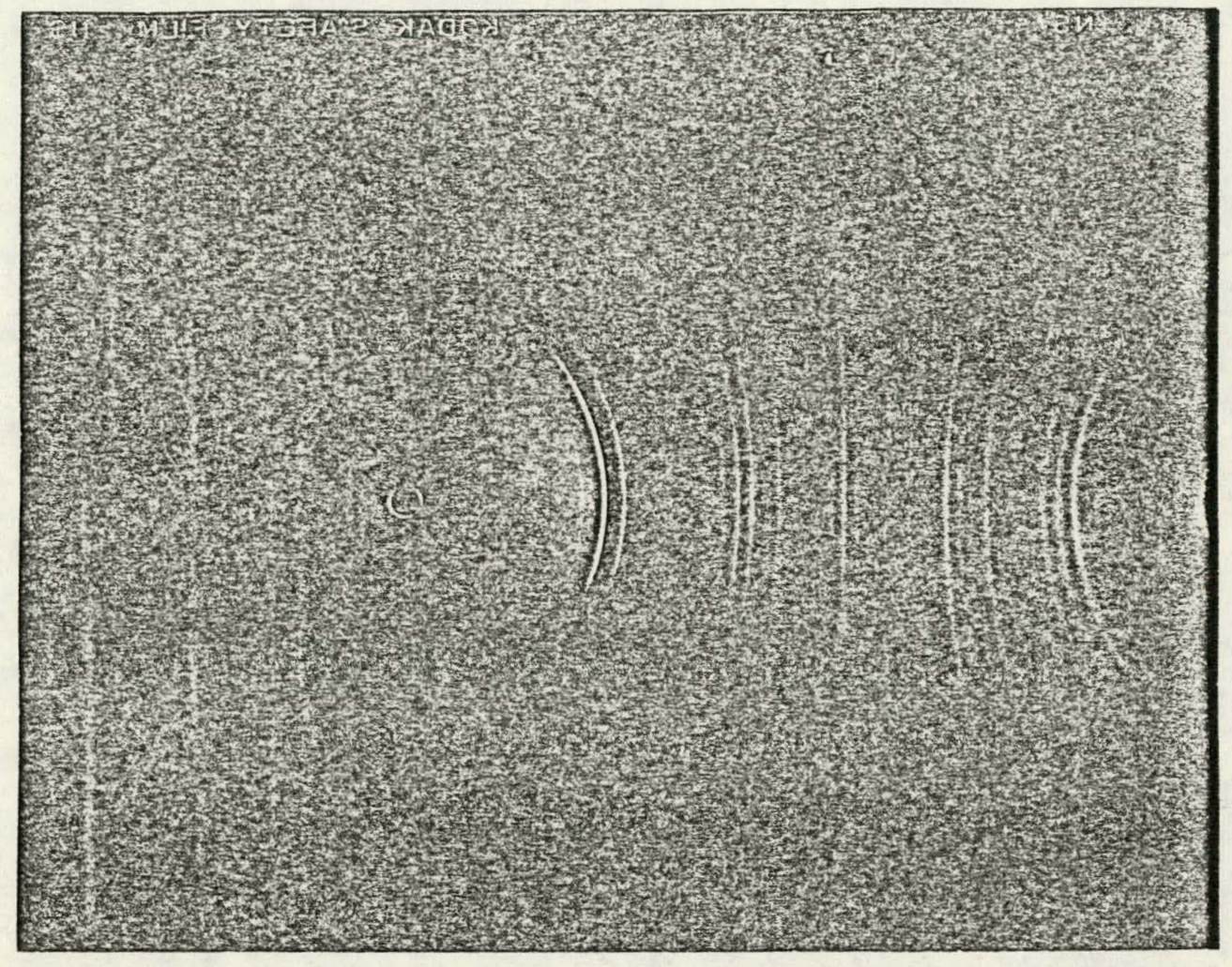

FIGURE 2. X-ray diffraction pattern for an undecomposed, metastable A-15 phase in an $\mathrm{Nb}_{75}\left(\mathrm{Al},{ }_{5} \mathrm{Ge}{ }_{25}\right.$ ) sputter deposit made at $20^{\circ} \mathrm{C}$ and heat treated 1 day at $750^{\circ} \mathrm{C}$. 


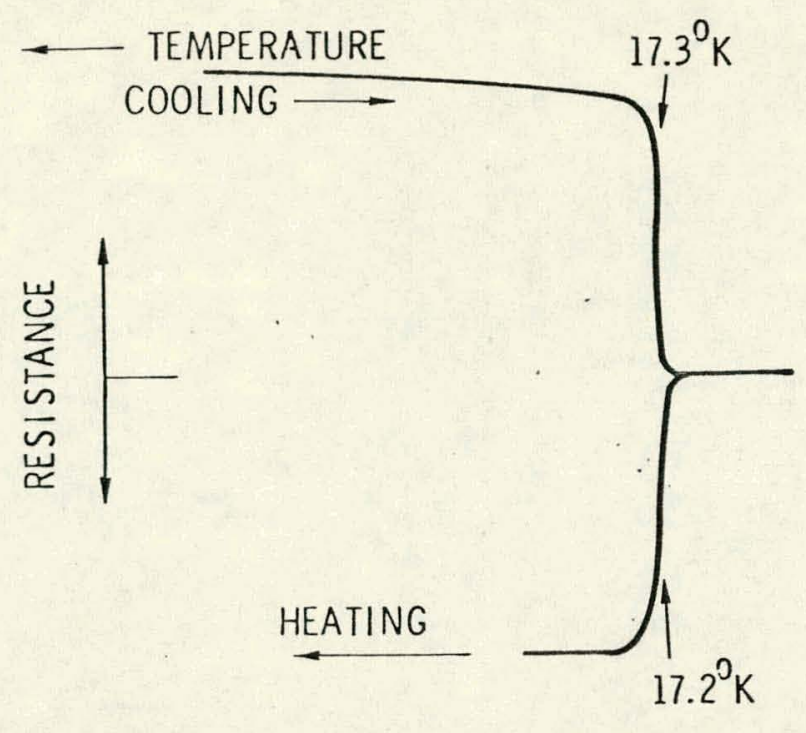

$\mathrm{Nb}_{3} \mathrm{AI}$ DEPOSITED AT $10^{\circ} \mathrm{C}$

AND HEAT TREATED 5 DAYS AT $750^{\circ} \mathrm{C}$

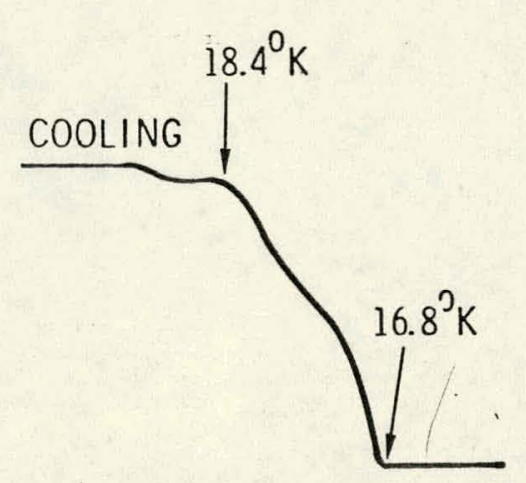

HEAT TREATED 5 DAYS

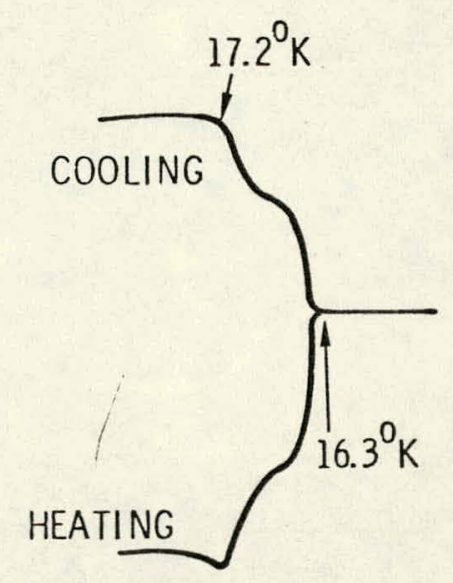

IIEAT TREATED 20 DAYS

$\mathrm{Nb}_{12} \mathrm{Al}_{3} \mathrm{Ge}$ DEPOSITED AT $10^{\circ} \mathrm{C}$ AND HEAT TREATED AT $750^{\circ} \mathrm{C}$

FIGURE 3. Critical transition temperature range for $\mathrm{Nb}_{3} \mathrm{Al}$ sputter deposited at $20^{\circ} \mathrm{C}$ and heat treated 5 days at $750^{\circ} \mathrm{C}$.

FIGURE 4. Critical transition temperature ranges for $\mathrm{Nb}_{3}\left(\mathrm{Al},{ }_{75} \mathrm{Ge} .{ }_{25}\right)$ made at $20^{\circ} \mathrm{C}$ and heat treated 5 days at $750^{\circ} \mathrm{C}$ (left) and 20 days at $750^{\circ} \mathrm{C}$ (right) . 


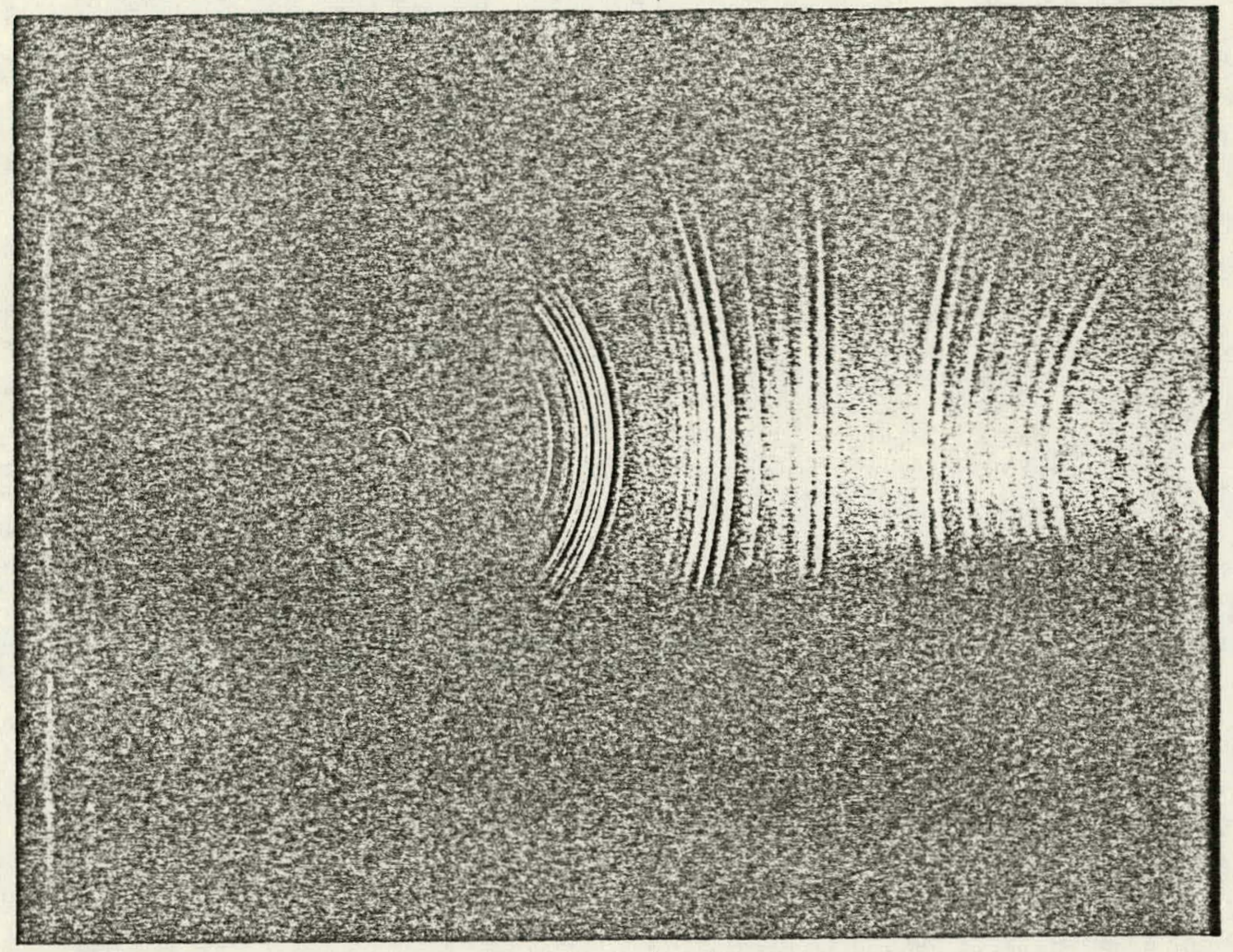

FIGURE 5. X-ray diffraction pattern for an $\mathrm{Nb}_{75}\left(\mathrm{Al}{ }_{75} \mathrm{Ge}{ }_{25}\right.$ ) deposit after heat treatment for two hours at $1240^{\circ} \mathrm{C}$ showing significant decomposition of the A-15 phase. 


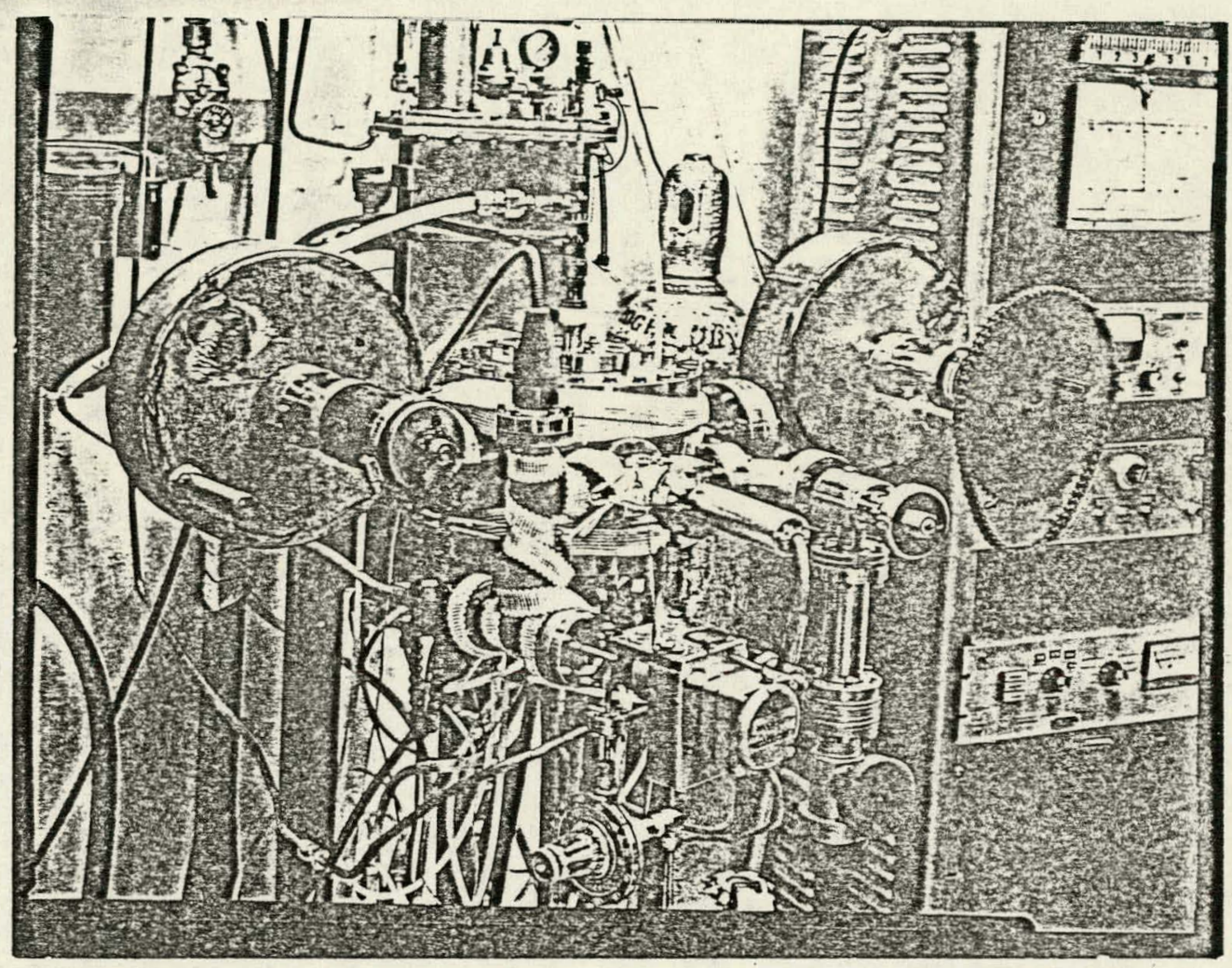

FIGURE 6. Assembled reel-to-reel equipment for sputter-deposition of Nb-Al$\mathrm{Ge}$ and $\mathrm{N}$ - Al superconductors on ribbon and filament substrates. 